[Livingstone, I. (2008). Editorial: Footprints and Shadows. New Zealand Annual Review of Education, 17, 1-4]

\section{Editorial: Footprints and Shadows}

\section{IAN LIVINGSTONE}

$\mathrm{I}^{\mathrm{n}}$ a recent Insight Programme from Radio New Zealand, ${ }_{1}^{1}$ an interesting distinction was made between footprints and shadows digital ones. A digital footprint is something we create about ourselves, through putting material on the web via email, sending text messages on cell-phones, using internet banking, uploading digital photographs, and more recently by sharing personal information on social networking sites such as Bebo and Facebook. A digital shadow, on the other hand, is something created by others about us, and begins from the moment of birth with the "Guthrie" heel prick test, and goes on through life, with passport information, now increasingly shared between government departments (and countries, such as Australia), driver's licence data, benefit records, not to mention the ubiquitous closed circuit TVs in banks, shops and service station forecourts, traffic cameras, eftpos records, cellphone data, and "cookies" placed on our computers by sites we visit on the internet. It has been estimated that now for the first time, the amount of digital information generated about us (of which we are likely to be unaware) exceeds the amount of digital information created by us. And it is estimated to be growing at the rate of $60 \%$ per year in New Zealand, with over $75 \%$ ending up on systems not under our control. This raises some very far-reaching privacy issues.

The latest development is "behavioural targeting", the detailed monitoring of our browsing habits by deep packet inspection (DPI), which allows marketers to place on our computer screens advertisements accurately-tailored to our individual interests, on the basis of what we have previously lingered over while surfing the web. This is a technology which has the power to do both good and evil, depending on who uses it, as Juha Saarinen notes in an article in the July 2008 issue of PC World. ${ }^{2}$ On the one hand, DPI can detect viruses and other computer malware that traditional detection systems may miss, and has the potential to combat the flood of spam infecting our in-boxes, by stopping it nearer the source. On the other hand, it permits governments to restrict what their populace is permitted to see on the internet (China has been known to block YouTube and blogging sites),

\section{Ian Livingstone}

and allows providers to engage in dubious traffic management practices on national computer networks.

In what I believe to be an entirely praiseworthy effort, the New Zealand Annual Review of Education now has its own distinctive digital footprint, and every article from its inception in 1991 up to the 16:2006 issue published in July 2007 can now be accessed in full-text PDF format on the Victoria University website at <www.victoria.ac.nz/nzaroe $>$. Access is free, unlike that of many other overseas journals. The School of Education Studies at Victoria University will continue to retain copyright of articles published, in both the hard copy and the on-line versions, but gives contributing authors full permission to deposit copies of their articles in other publicly accessible institutional repositories, under conditions which are outlined in the About Us page on the website. In particular, there is to be a delay of one year between the publishing of an article in hard copy and its appearing on the website, to allow editorial and publishing expenses to be met.

The current issue begins with two articles on evidence-based policy research. In the first, Noeline Alcorn, emeritus Professor of Education at the University of Waikato, in a revision of her Jean Herbison lecture at the 2005 annual conference of the Zealand Association for Research in Education, addresses widespread criticisms of educational research, examines the impact of the PBRF in New Zealand and the call for evidence-based practice, and then develops a set of principles for guiding future development in teacher education and educational research. In the second article, Nick Zepke, Associate Professor in the College of Education at Massey University, canvasses a series of questions relating to the practicalities of, and politics behind, evidencebased educational research, and the current emphasis on "what works". Written from a sceptical perspective, the article draws on experiences from the United States, the United Kingdom and New Zealand.

Peter Roberts, recently appointed Professor of Education at the University of Canterbury, provides an overview and critique of the Tertiary Education Strategy 2007-12, setting the Strategy in the context of earlier policy developments in the tertiary education sector. He argues that while some important changes have been made in the post-1999 "Third Way" years, economic concerns remain dominant in policy thinking, the commodification of knowledge has intensified, new forms of competition have emerged, and the language of reform has not changed as much as might have been expected.

In a jointly-written article with Rob Strathdee, a senior lecturer in the School of Education Studies at Victoria University, MEd student Karen Moses examines recent developments in the provision and 
funding of industry training in New Zealand. The article focuses upon the role Industry Training Organisations are expected to play in supporting the Labour-led coalition's Economic Transformation (ET) agenda, and explores some of the challenges created. The aim is to produce globally competitive firms by better directing the government investment in education and training and in research, science and technology.

In another jointly-written article, Lex McDonald, a senior lecturer in the School of Education Studies, and Liz Melchior, a lecturer in the School of Primary and Secondary Education, both at Victoria University, observe that more and more emphasis is being placed on course outcomes and on the relationship that universities have with their stakeholders. Their article highlights the importance of one of the keys to accomplishing such relationships - the development of teaching strategies that ensure transfer of learning occurs. A case study of a professional education programme in dance is outlined as an example of how planning for the impact of outcomes can be accomplished.

Next, Fiona Beals, lecturer in the School of Education Studies at Victoria University, considers two government policies developed outside the Ministry of Education, but with education and schooling in mind. The Youth Development Strategy Aotearoa (YDSA) and the Youth Offending Strategy (YOS) display somewhat contradictory ways in which the purpose and role of schooling are constructed. The author argues for the incorporation of a key strength of the YDSA - that of authentic youth participation.

We have two curriculum pieces in this issue. John Dickie, a senior lecturer in English literacy in the Faculty of Education at Victoria University, notes that Ministry of Education guidelines advocate that teachers reduce disparity in achievement by making connections between students' out-of-school and school literacies. This article offers examples of out-of-school literacies from a doctoral study which investigated literacy as social practice in family, church and neighbourhood sites as described by year 7 and 8 Pasifika students. It raises the question as to whether existing assessment approaches and teacher knowledge are sufficiently broad to accomplish the task. Next, Di Das, an MEd graduate in Māori and Pacific Islands Education from Victoria University, makes a strong case for "place-based", environmental education not to be regarded as an optional add-on to the school curriculum, displacing more important core subjects. She argues that schools can use place-based education to effect meaningful change in their local environment, whilst effectively covering most aspects of the school curriculum. By becoming involved in local issues, students can develop understandings of the democratic process, business development, and conservation practices.

Nancy Higgins and Jude MacArthur, researchers from the Donald Beasley Institute in Dunedin, and Missy Morton, principal lecturer in the School of Educational Studies and Human Development, University of Canterbury, argue that the 1996 Ministry of Education aim to develop a world-leading inclusive education policy has been lost, and the "clock is being wound back". More children are enrolling in Special Schools, in keeping with neoliberal ideologies focused on consumer choice, outcomes, and the view that education is a private good and not a human right. The focus is instead on "special" education policy, the maintenance of placement choice, and the surveillance and management of disabled students.

In our early childhood article for the issue, Maureen Woodhams examines the Labour-led coalition government provision of 20 hours free early childhood education in teacher-led services for all three- and four-year old children. This policy was linked to the goal of increasing participation in the government's strategic plan for early childhood education, by removing cost as a barrier to children's participation in approved services. The article concludes by suggesting that the initiative, while positioned by the Minister as an education policy, is as much about conditioning parents to place their young children in outof-home care so that they themselves can participate in the workforce.

Two assessment articles conclude the issue. Ella Kahu, currently teaching psychology at Massey University in Wellington, considers the role of external feedback in higher education settings. Following a summary of the effects of feedback on achievement and learning, she advocates some strategies for increasing its efficacy, particularly in regard to its timing and focus. Finally, in our usual article with a specific international theme, Martin Thrupp, Professor of Education at the University of Waikato, who spent 2000-05 carrying out research in London on the effects of target-setting, expresses his concern that a key education policy plank for the National Party going into the 2008 election is to be National Standards for primary and intermediate pupils in reading, writing and numeracy. These are seen to be more acceptable than the national testing which occurs in England and the United States. This article reviews evidence about the perverse effects of national testing, and reflects on whether what is proposed would prevent the problems which have been experienced overseas.

Notes

1. On <www.radionz.co.nz/national/programmes/insight/20080518>.

2 Saarinen, J. (2008, July). Bad phorm. PCWorld, p. 14 